\title{
Considering Human Vulnerability and Transhumanism: Some Theological Perspectives
}

\author{
Luis Miguel Torro Ferrero \\ Gregorian Pontifical University (Rome) \\ Catholic University of Valencia \\ Rome, Italy \\ E-mail: luistorroferrero@gmail.com
}

\begin{abstract}
The article proposes a reading on human vulnerability in today's technological context offering some theological perspectives. From a broad perspective on Transhumanism and Human Enhancement, it is suggested that the so called new technologies are proposing also a new understanding of the human being.
\end{abstract}

Keywords-Transhumanism; human enhancement; human vulnerability; memory

\section{INTRODUCTION}

Our epoch is undoubtedly marked by the scientifictechnological innovations and changes. We should acknowledge that these reshape the way in which we understand our world. This reality of profound change was, half a century ago, pointed out in the II Vatican Council. In its Pastoral Constitution Gaudium et Spes, it was suggested that those advances were also asking for a new comprehension of the human being, or a new humanism [1, 55].

Firstly, it is necessary to recognise the goodness and the greatness of the many important scientific and technologic breakthroughs bring in to our daily lives. Despite the difficulties that those advances might generate, it is important to keep all the goodness in mind. But a critical approach is essential as well.

In fact, I would suggest not focus on any specific technological advance, but to take into consideration the new frame of understanding that they produce, in particular the way in which we understand the human being.

Making a distinction between the advances in science and technology on the one hand and the interpretation that we make about those innovations on the other hand is vital, although the border between both is not always clear. Even more, technology is not neutral - but I'll leave this question for now.

\section{TRANSHUMANISM AND HUMAN ENHANCEMENT}

Focusing on the question about how to interpret these advancements, I would like to address the issue of transhumanism and human enhancement. As far as I am concerned, those movements (if we may define them as that) are, in fact, ways to interpret humanity in its relation to technology. In this essay, I will use both termstranshumanism and human enhancement - in a broad sense as not all the authors will recognize themselves as transhumanists. But let's define these terms first.

Human enhancement proposes the application of technology in people in order to increase human abilities or even get new ones. According to them, we should seize all the possibilities to get better faculties. Nevertheless, the meaning of "better" is always ambiguous.

Whereas, transhumanism - in this broad sense-makes reference to the idea that we, as humans, are in transition to become posthumans. In the most radical transhumanists approaches a posthuman is, in fact, a new species different to the human one. So, for transhumanists, a posthuman is the future stadium we will reach by the application of technology - specially the NBIC technologies — on humans.

It's clear that both concepts are not equal but they are closely related one to the other. In this essay, I will use both terms as synonymous.

The question that arises is what image of the human being can we find under these transhuman visions. And, to have a better understanding of this image, the idea of enhancement could be very interesting. If we wanted to enhance or improve the human, that would imply at least two important elements: the first one is that we are considering humans weak, poorly designed or defective, and the second one is that we think it is possible to do better. Otherwise we would not suggest trying to improve. All in all, it looks like that transhumanism basic premise is the human as defective beings seeking to improve themselves by technology.

Certainly, the idea of improve, especially if referencing moral improvement, has been present in almost every culture and religion. However, until now we were talking about personal and individual development by cultural means, in particular by education but also by meditation, prayer or so on... Transhumanism, on the other hand, is focused into other kind of improvement not by self-cultivation but by technology. I'll provide the reader with some examples in order to make things clearer. 
For instance, enhancing our memory, which is a good question as it offers an example of ambiguity. What would be better: to increase our capability to remember or to be able not to remember certain things? The answer depends on what as not always is good to remember everything. Of course, if we were students the night before an exam, we would like to easily memorize everything, with as many particularities as possible. But this, fortunately, is not always our situation. Sometimes it is better to forget, and the most extreme case is that exemplifies this assumption is the posttraumatic stress disorder (PTSD), which occurs after an extreme emotional trauma. In this case, the difficulty comes out of the impossibility to forget that trauma, which accompanies the person suffering from it all along, creating a continuous state of anxiety.

Recently, scientific research is allowing the use of certain drugs with the purpose of improving memory or forgetting more easily. These drugs are used in special situations of illness in order to heal. But what transhumanists propose is to extend the use of this kind of drugs not just as curative treatments but to enhance our capabilities, and this creates a serious moral debate.

Keeping in mind the PTSD example, it's known that one of the most traumatic experiences in war is the idea of killing your enemies and having to live with that image for the rest of your life. This fact produces in the soldiers a psychological damage that is very difficult to heal. Therefore, the technological solution would be to give them a drug (some kind of pills) that enabled them not to keep whatever happens during the day in their memory. Here the idea would not be recovering, but to acquire the new ability of not remembering. Naturally, advocates of transhumanism would say that although this would not be healing, it would be preventing a future illness such as the PTSD. This example allows us to see the important problem arising from this kind of improvements: the meaning of healing begins to blur too. The borders between healing, preventing illnesses and enhancing are not always clear. But again, we are not interested in the moral consequences of this discourse; we leave the debate for the experts in Moral and Ethics.

\section{THE QUESTION ABOUT THE HUMAN}

What we propose is entering into the analysis of the image of the human being behind these proposals. Returning to the idea of memory, we could realize our vulnerability and fragility. Our capacity to remember, which allows to have our own identity among other important things, seems to be fragile and even problematic as it can produce, as we have just exemplified, even illness.

It's clear that if we compare our memory with computer memory, at a first glimpse, it looks like our system fails since it is unable to reproduce the things we would like to remember with exactitude. Whereas when we look at a picture from some time ago in the computer we know that what we see is exactly as it was originally. To be fair, it could be interesting to state that computer memory is not perfect either as it can be lost: can be deleted by mistake or by a computer virus, or even the device can be broken or damaged, and so on.

A transhumanist approach would propose improving our memory by getting those abilities related to memory that a computer has. The way to do it could be by pharmacological means or by a technological implant, but for our purpose, the technical means would be not important.

Coeckelberg [2, p. 4] gives us a key in facing the problematic understanding of the human being in transhumanism. Despite I don't agree with him in the whole of his proposals, it's very interesting what he is pointing out. It seems that transhumanism proposes a reduction, even elimination of our fragility and vulnerability by technology. We have just talked about the problem of forgetting or remembering, which would be a vulnerability for transhumanists, easily reduced or eliminated by taking some pills or introducing an implant in our brain.

Despite this, Coeckelbergh makes an interesting contribution. According to him, the best we could hope for, is the transformation of our own vulnerabilities. Transforming only, never eliminating them at all. History has taught us that when we have been able to reduce some kind of vulnerability, some other has appeared.

From my point of view, in the back of many transhumanists proposals there is an authentic spirit of purpose of a better world. And we should be careful with this, especially if we focus on the technological advancements because, once more, many of them have improved noticeably our daily lives. Nevertheless, I am not proposing a return to pre-modern world. My point is that even recognizing the important role of science and technology in the improvement of our lives, this is not enough. This is not really a new contribution as for instance at the Catholic Church Magisterium in 1961, pope John XXIII, in Mater et Magistra, stated the question:

After all this scientific and technical progress, and even because of it, the problem remains: how to build up a new order of society based on a more balanced human relationship between political communities on a national and international level? [3, 212]

The solution, according to the pope, comes from a better understanding of the human being in all its dimensions. Seeing that, one of the most serious problems of those transhumanist proposals is that they offer an unreal vision of humans as invulnerable beings (youth and health). The image of the human being that is able to avoid all the difficulties by technological means, and only by technological means, is illusory. This illusion is being supported by techno-enthusiastic who believe in human beings capable of becoming invulnerable and almost technologically immortal.

A weak understanding of the human being is the real risk of transhumanism, because, against that vision of the human as invulnerable beings, Lambert reminds us that: «Human being has its limits and the hope in the utopic creation of a (trans)humanity without limits and without vulnerability it is potentially dehumanizing» [4, p. 110 (translation is mine-)]. 


\section{Human Beings Are Vulnerable}

To avoid the risk of dehumanization, it is important to understand individuals, and rediscover the value of vulnerability in its double sense: 1) that humans as relational beings are finite and vulnerable; and 2) that those who are more vulnerable should not be forgotten.

In order to do so, we should to look at human vulnerability in its deepest sense. A personalistic approach to human beings points out the need of relating with others and this renders us vulnerable. A person cannot be a isolated being but needs to open and interact with others [5, p. 46]. Moreover, they sustain that others play an important role in the construction of our one-self [6, p. 68].

For this reason, we should have a closer look at meaning of vulnerability, as Stalsett explains:

For our purposes here, human vulnerability may be taken to mean the ability to be corporeally, mentally, emotionally, and existentially affected by the presence, being, or acting of another or something other. [...]

In this sense, human vulnerability is irremovable. Every human being is vulnerable, at every moment of her life [7, p. 468].

Of course, understanding human vulnerability is challenging as in many occasions it is seen as sign of weakness [8, p. 121], when in fact it shows our being relational and finite. Even more, it is the possibility of our happiness, as Gandolfo says:

as unattractive as our exposure to harm may be, vulnerability is also the condition for the possibility of existence itself, along with the possibility of goodness and flourishing. Human life and happiness are only achievable within the contours of our fragile, finite existence [9, p. 25].

But, let me return to our example of the memory. It seems that a transhumanistic solution would be to increase our capability to remember. However, it's not as simple as just adding a flash memory to enlarge this retentiveness. Because human memory has its own complex mechanisms that allow us to remember things, which may be important for us, and forget others. Also from a theological perspective, Granados [10] makes an important development on the question of the memory and brings out the tale of Borges Funes, His Memory. This story tells us the drama of Funes an eccentric guy who wasn't able to forget,

Not only was it difficult for him to see that the generic symbol «dog» took in all the dissimilar individuals of all shapes and sizes, it irritated him that the «dog» of threefourteen in the afternoon, seen in profile, should be indicated by the same noun as the dog of three-fifteen, seen frontally [11, p. 136].

This incapability to forget does not allow Funes to think, as Borges states: «I suspect, nevertheless, that he was not very good at thinking. To think is to ignore (or forget) differences, to generalize, to abstract» [11, p. 137].

I've just put the question of memory as an example to show the difficulties that come along with the several proposals about enhancement, and the question about what is needed to be improved.

Once more, let me insist in the beneficial role of technology advancements in the areas of dependent people. An interesting case, just as an example, of the use of technology is the e-NABLE community [http://enablingthefuture.org] which helps in the design of 3D printable open-source prosthetics. According to them, between July of 2013 to June 2015, they had delivered 1500 hands in more than 40 countries.

I don't share Stalsetts view when she proposes «seeing human vulnerability as a value to be promoted and protected, not removed» [7, p. 471]. Even though I understand she is talking of vulnerability in the sense of being relational, we should be careful in the ambiguity that comes with the term vulnerability. And, talking about vulnerability, attention should be paid to those who are more vulnerable, or even weak, and being open to mutual encountering.

When our technological advanced societies propose as the model a young and healthy person we have the peril of underestimating those who are not in this position. Consequently, we are losing the important role that they might be exercising in our societies.

In this technological era, mutual encountering and the combination of the strength of ones with the weakness of others should be sought. And, in this sense, Jean Vanier, founder of l'Arche, proposals of vulnerable and dependent people touching, complementing and transforming the stronger ones [12, p. 11] are truly inspiring. The encounter between the weak and the strong should be, according to him: «an interaction in which the weak can find a certain security and develop, and the strong can learn to accept their own vulnerability and discover the real meaning of human life» [13, 2010:2013].

My own feeling on the subject is that the major problem when facing the transhumanist proposals is precisely that they are promoting a battle against the most vulnerable. To sum up, the problem is not technology by itself but this way of understanding the human being.

I have no objection with transhumanists affirming that the seek for perfection has been a constant in the history of humanity. But Waters makes an interesting point in the question when he suggests considering transhusmanism as a revival of heresies like Manicheanism or Pelagianism. Since they claim for self-perfection. According to Waters, the issue is not the quest for perfection but the rejection of imperfection. The risk in those heresies and in transhumanism is that the quest for perfection cannot ultimately tolerate the imperfect. Regardless how perfection might be defined - for example, as a perfect body, soul, or will- that which remains imperfect or lacks the capability of being perfected should be eliminated or prevented [14, p. 171]. 


\section{CONCLUSION}

In conclusion, when transhumanists support this search of a better human, when they seek to enhance capabilities and to improve human beings, there is an implicit and wrong vision about humanity. That vision is about a perfect young and healthy ideal person. But life teaches us that there is not such a thing as the ideal human. Human beings are relational beings that have need of others, and that makes us vulnerable to others.

Instead of looking up to invulnerability, I suggest recognising our own vulnerability in its ambivalent circumstances, as the capability of being hurt but also in the way of loving others and being loved by others. Appreciating vulnerability should lead us the realisation of those who are especially vulnerable, and to being open to them. To being able to recognise their important role in societies, that in many occasions advance towards technological development but at the same time forget the role of love and compassion.

Only by loving and being more compassionate; only acknowledging our own vulnerability, will be able to be better-humans, to really improve our humanity.

\section{REFERENCES}

[1] II Vatican Council, Gaudium et Spes.

[2] M. Coeckelbergh, Human being @ risk: enhancement, technology, and the evaluation of vulnerability transformations, vol. 12. Dordrecht: Springer Netherlands, 2013.

[3] John XXIII, Mater et Magistra.

[4] D. Lambert, «Faut-il se libérer de la fragilité? Questions posées par une robotisation des activités humaines», in Fragilité, dis-nous ta grandeur! Un maillon clé au sein d'une anthropologie postmoderne, B. Ars, Ed. Paris: Les éditions du cerf, 2013, pp. 13-30.

[5] J. M. Burgos, Antropología: una guía para la existencia, 5th ed. Madrid: Palabra, 2013.

[6] T. Mifsud, Una espiritualidad desde la fragilidad. Mensajero, 2016.

[7] S. J. Stalsett, «Towards a Political Theology of Vulnerability Anthropological and Theological Propositions», Polit. Theol., vol. 16, n. ${ }^{\circ}$, pp. 464-478, sep. 2015.

[8] G. M. Otalora, Compasión y misericordia. Madrid: San Pablo, 2014.

[9] E. O. Gandolfo, The power and vulnerability of love a theological anthropology. Minneapolis: Fortress Press, 2015.

[10] J. Granados, Teología del tiempo: ensayo sobre la memoria, la promesa y la fecundidad. Salamanca: Ediciones Sígueme, 2012.

[11] J. L. Borges, «Funes, His Memory», in Collected fictions, New York, N.Y., U.S.A: Viking, 1998.

[12] J. Vanier, Toute personne est une histoire sacrée. Paris: Plon, 1994.

[13] J. Vanier, Signs of the times: seven paths of hope for a troubled world. [e-Book] London: Darton, Longman and Todd Ltd, 2013.

[14] B. Waters, «Whose Salvation? Which Eschatology? Transhumanism and Christianity as Contending Salvific Religions», in Transhumanism and Transcendence: Christian Hope in an Age of Technological Enhancement, R. Cole-Turner, Ed. Washington DC: Georgetown University Press, 2011, pp. 163-175. 